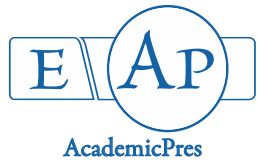

\title{
Temporal and Spatial Variations in Abundance and Diversity of Zooplankton Fauna of Opa Reservoir, Obafemi Awolowo University, Ile-Ife, Southwest Nigeria
}

\author{
Oluseun Peter BOLAWA ${ }^{1 *}$, Adebukola Adenike ADEDEJI ${ }^{1}$, \\ Yetunde Folasade TAIWO ${ }^{2}$ \\ IObafemi Awolowo University, Department of Zoology, Ile-Ife, Nigeria; bolawaoluseun@gmail.com ("corresponding author) \\ ${ }^{2}$ Obafemi Awolowo University, Natural History Museum, Ile-Ife, Nigeria
}

\begin{abstract}
The present study investigated the ecological status of Opa reservoir, Obafemi Awolowo University, Ile Ife, Nigeria, based on the spatial and temporal variations in abundance and distribution of zooplankton. 72 samples were collected monthly with a quantitative net zooplankton from both the surface and bottom levels in three stations established at the dam site (Lacustrine), mid-lake (Transition) and inflow (Riverine) over a period of an annual cycle. A total of fifty-four (54) species were recorded from the reservoir comprising Rotifera $(57.41 \%)>$ Arthropoda $(33.33 \%)>$ Protozoa $(5.56 \%)>$ Ciliophora $(1.85 \%)=$ Cnidaria $(1.85 \%)$, in the order of abundance. The least number of species (47) was recorded at the Transition station, while the highest number of species (49) occurred at the Lacustrine zone. Of all the zooplankton recorded, four species had significant spatial variation, while nine displayed seasonal variations during the study period $(\mathrm{p} \leq 0.05)$. The highest species richness was observed in Transition surface station (4.18), followed by Lacustrine surface station (3.80) and Riverine surface station (3.23). Shannon's index showed that zooplankton species were more diverse during the rainy season than dry season. The highest Trophic State Index (TSI ${ }_{\mathrm{CR}}$ ) with respect to Rotifer abundance occurred in Transition surface, followed by Riverine surface and the least occurred in Transition bottom portion. The mean TSI $\mathrm{CR}_{\mathrm{R}}$ value obtained was 65.20 , indicative of hyper-eutrophic, while the mean TSI ${ }_{\mathrm{CL}}$ value with respect to cyclopoida-calanoida obtained was 58.07 also revealing eutrophic status of the study area. Opa reservoir comprises mainly Rotifers and its TSI $_{\mathrm{CR}}$ showed the lake as eutrophic, tending towards becoming hyper-eutrophic, which could speed up the aging of the lake.
\end{abstract}

Keywords: Opa reservoir occurrence; spatial variation; species richness; temporal variation zones; trophic state index

\section{Introduction}

Zooplankton are passive drifters, moving with water currents, yet well adapted for their mode of life, hence can withstand diverse levels of environmental changes in physicochemical water quality, thereby useful for measuring the status of their environment (Paterson, 2001; Imoobe, 2011; Akindele and Adeniyi, 2013). Zooplankton also serve to link up the lower trophic level comprising of phytoplankton which are primary producers to the macroinvertebrates and fishes, which occupy a higher trophic level of the ecosystem (Akindele and Adeniyi, 2013). The zooplankton assemblage often influences energy flow through classical food chain, nutrient cycling and community population dynamics within a reservoir ecosystem. This ecological niche has made them key actors in top down grazing effect (trophic cascade) on the bottom up forces which play pivotal roles in bio-manipulation for lake restoration purposes as reported by Carpenter and Kitchell (1993).

Despite this enormous role played by zooplankton in waterbodies, their distribution has been reported to be affected by factors such as the hydrologic regime of the waterbody (Casanova and Henry, 2004), physical and chemical variables (Sarkar and Chaudhary, 1999; Arimoro and Oganah, 2010), drainage density, sinuosity ratio and stream frequency (Akindele and Adeniyi, 2013), hydrological characteristics (Mitsch and Gosselink, 2000). According to Adedeji et al. (2011), their occurrence was found to be directly related to the concentration of the nutrient in the waterbody. Plankton is equally susceptible to a wide range of environmental factors such as water physicochemical properties comprising of temperature, light, $\mathrm{pH}$ range, oxygen, salinity and toxic contaminants (Paterson, 2001). 
266

Adesakin et al. (2017) reported direct discharge of untreated municipal/industrial waste, as well as run off from agricultural areas into Opa reservoir, whose effect on the reservoir's physicochemical parameters was significant both temporally and spatially; this could pose a level of risk to the inhabiting aquatic ecosystem. The last record of plankton research carried out on the reservoir, about eighteen years ago (Akinbuwa and Adeniyi, 1991), noted Rotifers only. The present study, therefore, attempts to evaluate the distribution of zooplankton fauna in Opa reservoir through an annual cycle with a view to determine the effects of the recent dredging of the inflowing River Opa and other smaller streams within the catchment basin. The study would also reveal the present ecological and trophic status of the reservoir.

\section{Materials and Methods}

\section{Study area}

Opa reservoir is sited between latitude 07030 ' $\mathrm{N}$ to $07031^{\prime} \mathrm{N}$ and longitude $004031^{\prime} 40 " \mathrm{E}$ to $004032^{\prime} 45^{\prime \prime} \mathrm{E}$, within the Obafemi Awolowo University community, IleIfe, Southwestern Nigeria (Fawole and Arawomo, 2000). The artificial lake was built on the Opa River within the University community in 1978 (Fig. 1) and the project was eventually completed and commissioned in 1979 (Akinbuwa and Adeniyi, 1991). Opa reservoir has a catchment area covering parts of Ife central, Ife East and Atakumosa West Local Government Areas of Osun state, Nigeria. Opa reservoir is one of the African tropical reservoirs, small and shallow, a knowledge of which can be of benefit to the management of the reservoir in meeting its primary need of water supply and secondarily, as a source of fisheries.

\section{Water sampling}

Three sampling stations were established as follows: location A for Lacustrine portion, close to the dam wall; location $\mathrm{B}$ at the midlake (Transition) and location $\mathrm{C}$ for the Riverine portion, towards the inflow of the lake. The coordinates and depths of the three sampling stations as well as their respective depths can be found in Table 1 .

Water sampling was done between November 2012 and October 2013 covering a period of one year for the zooplankton analysis. Water was collected with an improvised water sampler of $2.5 \mathrm{~L}$ capacity used to take bottom water samples and then $20 \mathrm{~L}$ of water were sieved through a plankton net of $50 \mu \mathrm{m}$ mesh size and then strained into a universal bottle of about $30 \mathrm{ml}$ and preserved with both Lugol solution and few drops of 5\% formalin before being taken to the laboratory for analysis. In the laboratory, a plankton chamber of about $1.5 \mathrm{ml}$ capacity was filled with the preserved water sample to be viewed under the microscope using an Omax binocular light compound photo-microscope (Model Number: G013050830). Scaled pictures were taken and measurements of identified plankton were also recorded.

Identification of planktonic species was later done based on standard identification guides and keys prepared by Jeje and Fernando (1986), Fernando (2002).

\section{Estimation of plankton abundance and trophic status}

On each of the concentrate taken on the plankton chamber, a count was made so as to estimate the planktonic population abundance with respect to the volume of the sub-sample and to the original volume of water filtered with plankton net. The results were then expressed in organisms per cubic metre of the original water sample (Goswami, 2004):

$$
\mathrm{A}=\frac{a b}{a} \times 1,000
$$

where:

A - Abundance of species per litre of original water source; $\mathrm{a}$ - Abundance of species in the subsample; $\mathrm{b}$ Total concentrate volume of water used $(1.5 \mathrm{ml}) ; \mathrm{c}$ Original volume of water $(20 \mathrm{~L})$.

The above equation was used to estimate the abundance of zooplankton species.

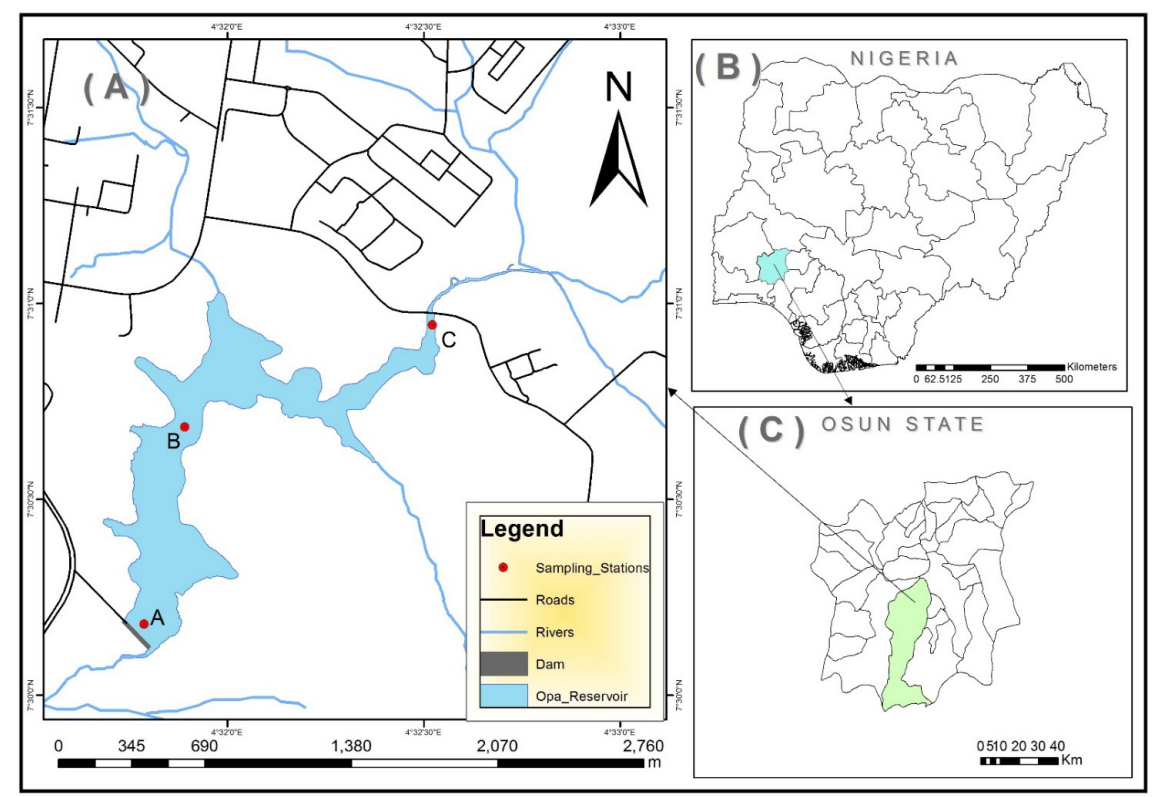

Fig. 1. Map of Opa Reservoir showing the sampling stations 
Table 1. Grid location of selected sampling stations

\begin{tabular}{|c|c|c|c|c|}
\hline Stations & Longitude & Latitude & Elevation $(\mathrm{m})$ & Depth (m) \\
\hline Lacustrine (A) & $07^{0} 30^{\prime} 13.0^{\prime \prime} \mathrm{N}$ & $004^{0} 31^{\prime} 45.7^{\prime \prime} \mathrm{E}$ & $240 \pm 10$ & 6.01 \\
\hline Transition (B) & $07^{0} 30^{\prime} 284^{\prime \prime} \mathrm{N}$ & $004^{0} 31^{\prime} 830^{\prime \prime} \mathrm{E}$ & $245 \pm 07$ & 4.99 \\
\hline Riverine (C) & $07^{0} 30^{\prime} 45.0^{\prime \prime} \mathrm{N}$ & $004^{0} 31^{\prime} 10.5^{\prime \prime} \mathrm{E}$ & $252 \pm 08$ & 1.22 \\
\hline
\end{tabular}

In determining trophic status of a water body, few quantitative models have been developed. Duggan et al. (2001) developed a potential Rotifer bio-indicator schemes for lake trophic state using TLI (Burns and Rutherford, 1998) and traditional OECD, taken into consideration the following:

i. Indicative species of eutrophic waters

ii. Indicative species of Mesotrophic and Oligotrophic waters

iii. Number and diversity of species

iv. Mean zooplankter weight, mean Cladoceran weight, mean Rotifer weight and mean copepod weight

v. Rotifer abundance

vi. Percentage of Rotifer in total plankton abundance

vii. Ratio of abundance of large Cladocerans to abundance of all Cladocerans

viii. The ratio of Calanoids to Cyclopoids abundance

ix. Ratio of Crustacean abundance to Rotifer abundance (Haberman and Haldna, 2014).

The model proposed by Ejsmont-Karabin (2012) was used to estimate the trophic status of the reservoir:

TSI $_{\text {ROT }}=5.38 \operatorname{Ln}(\mathrm{N})+19.28$

where $\mathrm{N}$ is the abundance of Rotifers in Ind/L

and $\mathrm{TSI}_{\mathrm{CR}}=5.08 \mathrm{Ln}(\mathrm{CY} / \mathrm{CA})+46.6$

where CY is the abundance of Cyclopoida; CA is the abundance of Calanoida in Org/L, according to EjsmontKarabin and Karabin (2013).

For the interpretation of the results the following were considered: TSI $<45=$ Mesotrophic; TSI $(45-55)=$ Meso-eutrophic; TSI $(55-65)=$ Eutrophic; TSI $>65=$ Hypertrophic lake.

\section{Qualitative analyses and statistical procedures}

The reagent bottles and other sampling bottles were washed with detergent and subsequently rinsed severally and thoroughly with tap water and distilled water before use. Other procedures were followed duly. In order to ensure good results were obtained during the course of the sampling, certain necessary precautions were taken into consideration.

Data collected were subjected to various descriptive and inferential analyses such as the means and standard deviations which revealed planktonic species abundance with respect to season and location. Analysis of Variance (ANOVA) was used to compare mean abundance of identified planktonic species while correlation was used to estimate the strength of relationship between various planktonic groups. Moreover, Principal Component Analysis (PCA) was used to reduce all interactions into components that also showed the relationship among recorded plankton species as applicable using SPSS Version 21 software (SPSS, 2012).

\section{Results}

A total of fifty-four (54) species of zooplankton were recorded belonging to thirty-five (35) genera, twenty-four (24) families, thirteen (13) orders, ten (10) classes and five (5) phyla of zooplankton, as summarized in Table 2 and Fig. 2. Temporally, nineteen zooplankton (19) species occurred in either of the two seasons, while thirty-nine (39) species were found in both seasons. A total of fifty-one (51) species occurred in the rainy season and forty-four (44) in the dry. Of the species recorded, the season had effect on nineteen species (19), which were recorded either during dry or rainy season only; these include a Protozoan (Vermamoeba vermiformis), a Ciliophora (Favella attingatai), thirteen members of phylum Rotifera (Asplanchna sp. 1, Asplanchna sp. 2, Argonotholca sp. 2, Anuraeopsis fissa, Brachionus urceus, Ascormorpha sp., Ascormorpha ecaudatus, A. ecaudis, Filinia opoliensis, Polyarthra dolichoptera, Polyarthra remata, Trichocerca cylindrica, Horaella brehmi) and four species of Arthropoda phylum (Mesocyclops sp., Calanus sp., Hesperocorixa obliqua, Hydrozoa actinula) (Table 3).

Spatially, a total of 37 species were found in the three sampled stations both at the surface and bottom water (Table 3). Species that occurred specific to a station were Vermamoeba vermiformis and Hydrozoan actinula as recorded from bottom portion of Lacustrine and Riverine stations respectively. Some members of the phylum Rotifera namely Argonotholca sp. 2 and Ascormorpha ecaudatus were also recorded at the bottom portion of the Riverine station only, while Asplanchna sp. 1, Asplanchna sp. 2, Anuraeopsis fissa, Brachionus urceus, Ascormorpha sp. were also recorded specific to Riverine, but at the surface water (Table 3). The least number of species (47) was recorded from Transition station and the highest (49) occurred at the Lacustrine zone of the reservoir (Table 3 ).

The highly abundant species include Asplanchna berrickii, A. priodonta, Keratella crassa, Brachionus falcatus, Ascormorpha ovalis, Trichocerca flagellata, Discorbis sp., Copepod nauplii, Copepod larva, Cyclops vicinus, Macrocyclops albidus, Diaphanosoma brachiurum, Acanthocyclops sp. and Senecella calanoides.

Statistically significant seasonal difference were shown by Trinema sp., Hesperocorixa obliqua and Favella attingata ( $\mathrm{p}$-0.05), while Asplanchna herrickii, A. priodonta, Brachionus falcatus, Trichocerca flagellata, T. bicristata and Chironomid larvae showed highly significant differences between the two seasons ( $\mathrm{p} \leq 0.01)$ (Table 4). Recorded species that showed statistically significant difference spatially included Trinema sp., Macrocyclops albidus and Favella attingata ( $\leq 0.05)$, while Trichocerca flagellata had a highly significant difference $(\mathrm{p} \leq 0.01)$ (Table 5$)$. 


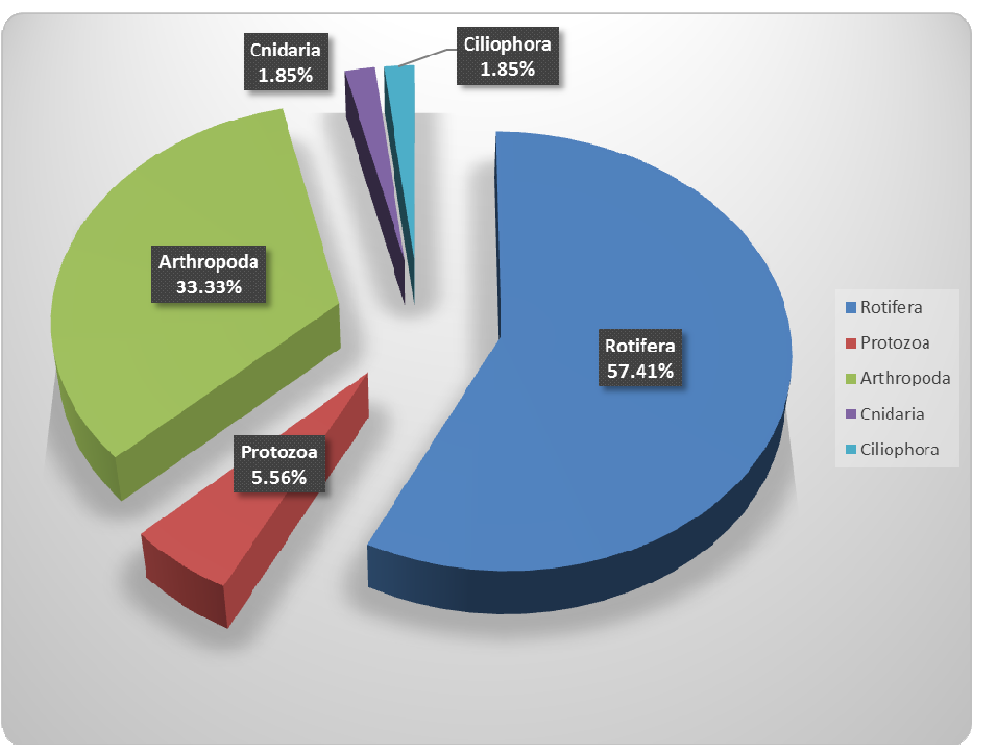

Fig. 2. Taxonomic composition of recorded species of zooplankton taxa

Table 2. Outline classification and taxa composition of the zooplankton fauna

\begin{tabular}{ccccccc}
\hline Phylum & Class & Order & Family & Genus & Species & Percentage occurrence (\%) \\
\hline Protozoa & 3 & 3 & 3 & 3 & 3 & 5.56 \\
Cnidaria & 1 & 1 & 1 & 1 & 1 & 1.85 \\
Ciliophora & 1 & 1 & 1 & 1 & 1 & 1.85 \\
Rotifera & 1 & 2 & 8 & 12 & 39 & 57.41 \\
Arthropoda & 4 & 6 & 11 & 35 & 54 & 100.00 \\
TOTAL & 10 & 13 & 24 & &
\end{tabular}

Table 3. Spatial and temporal occurrence of zooplankton and related species

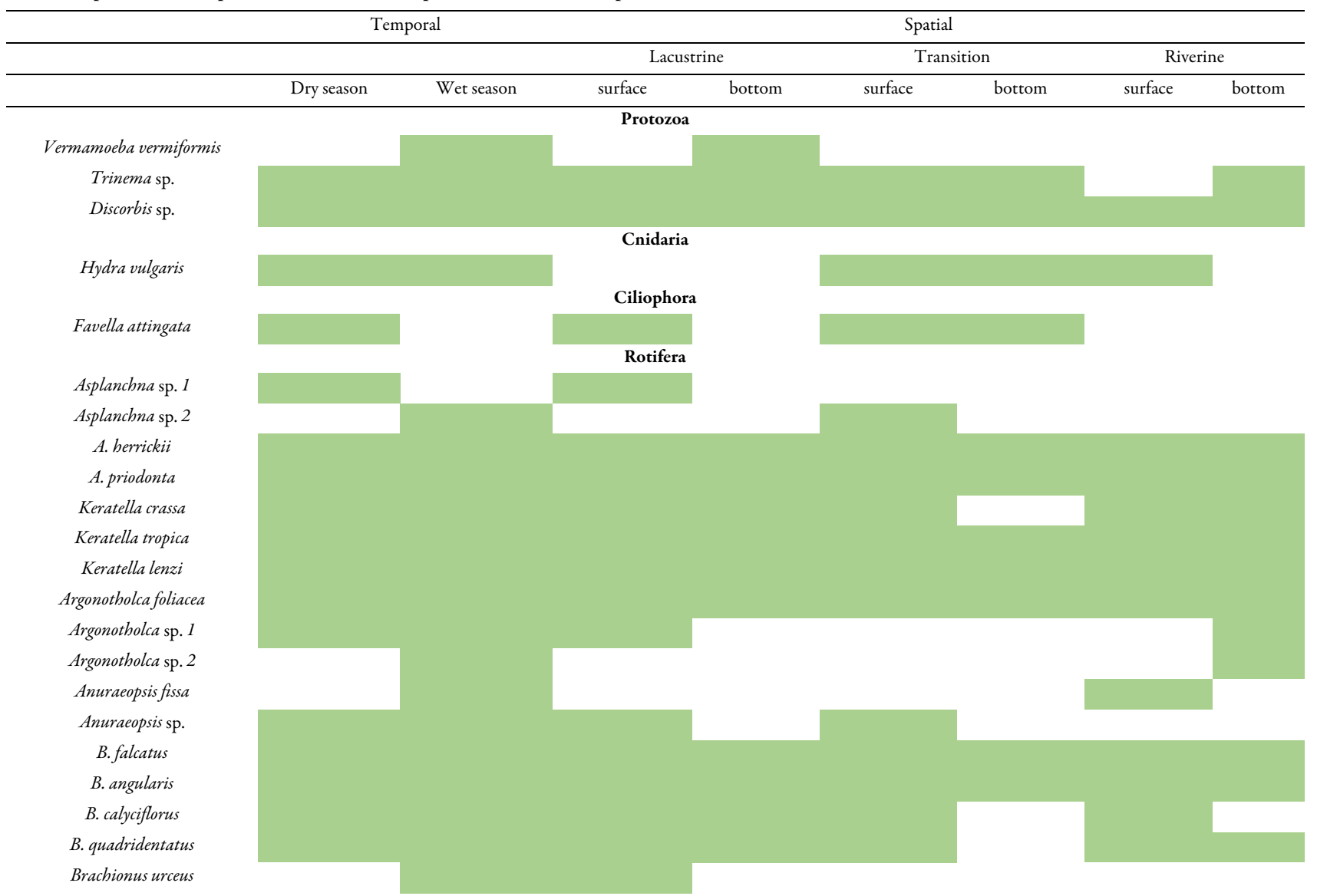




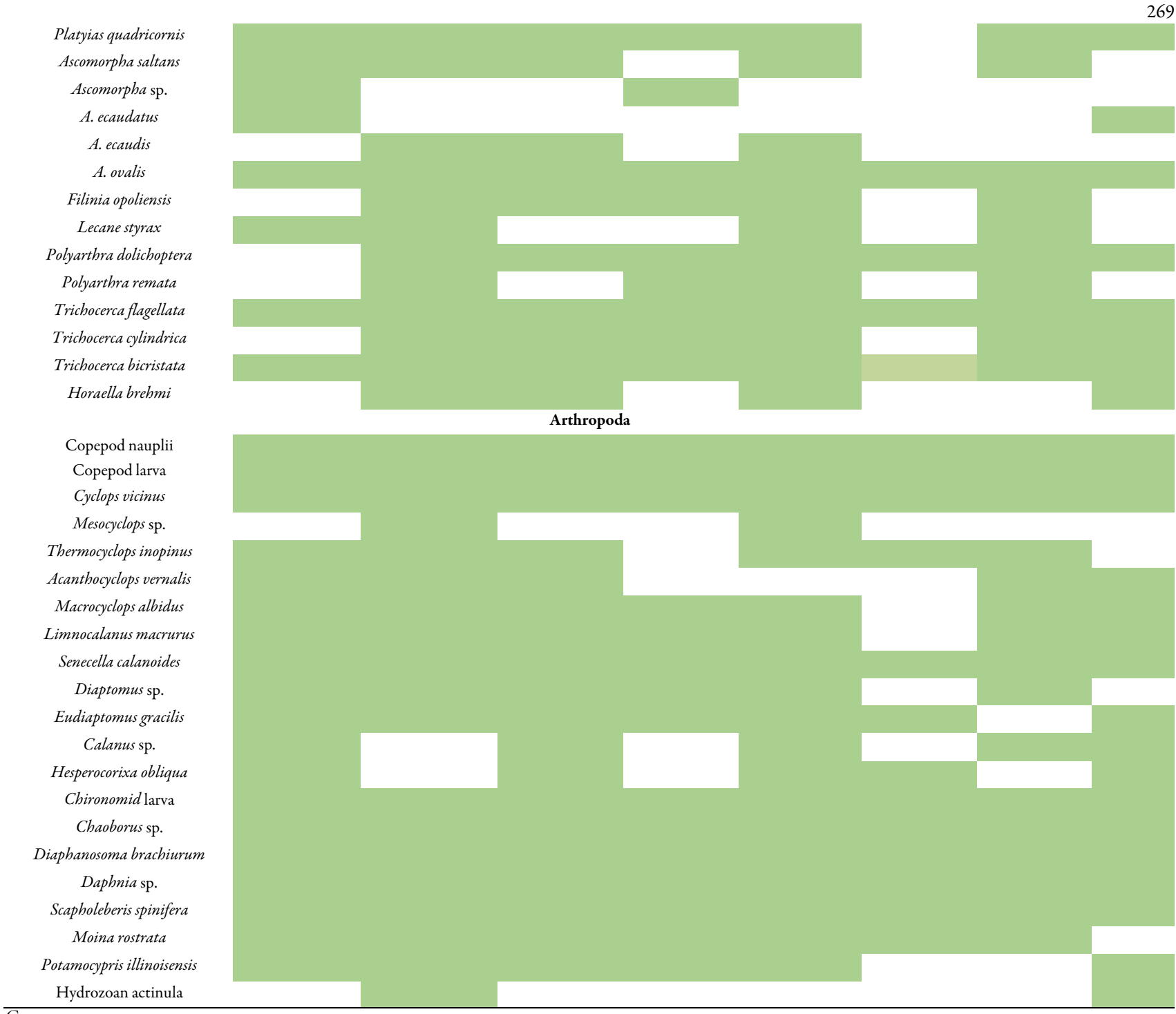

The highest species richness was observed in Transition surface station (4.18) followed by Lacustrine surface station (3.80) and Riverine surface station (3.23) (Table 6). These values were higher than the recorded species richness of their corresponding bottom stations. Such a result implies that more species were recorded in the surface portion than the bottom. Shannon index also showed a similar pattern spatially, with the highest value at Transition surface station, thus corroborating the highest number of species and abundance recorded at the Transition station of the reservoir.

Seasonally, Shannon's index showed that the recorded zooplankton species were more diverse during the rainy season than in the dry season. The result was further confirmed by Hill's first diversity index (N1), which revealed that 26 species were abundant in the wet season compared with 14 species in the dry season. Spatially, Hill's diversity indices showed that 26 species (highest value) were abundant at the Transition surface portion, while 13 species (the least value) at the Lacustrine surface (Table 6).

Principal component analysis was used to check the correlation of the planktonic organisms recorded. The result of the analysis revealed twenty-one significant $(\mathrm{p}<$ 0.05 ) components with a cumulative variance of $84.92 \%$. Component 1 showed a strong positive correlation for nine (9) species with variance of $10.95 \%$. The strongest loading of 0.929 revealed positive correlation between Asplanchna sp. 2 (Sp 2) and Acanthocyclops vernalis (Sp 40), while Keratella lenzi (SP 7), Brachionus falcatus (Sp 13), Horaella brehmi (Sp 31), Trinema sp. (Sp 33), Mesocyclops sp. (Sp 38), and Scapholebris spinifera also showed strong positive correlation within Component 1 . Component 2 revealed correlation between highest number of species with strong positive loading, 14 different zooplankton species contributing $7.76 \%$ of the total variance.

Brachionus urceus (Sp 17) and Platyias quadricornis (Sp 18) with strong loadings, and moderate loadings for Keratella tropica (Sp 6), Discorbis sp. (Sp 34), Copepod nauplii (Sp 35), Limnocalanus macrurus ( $\mathrm{Sp}$ 52) and Chaoborus sp. (Sp 59) (Table 7). The highest Trophic State

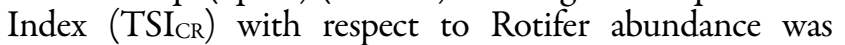
recorded for Transition surface station, followed by Riverine surface and the least occurred in Transition bottom portion. The mean value obtained was 65.20 , which 
Table 4. Seasonal variation of aquatic microfauna between dry and wet seasons under study

\begin{tabular}{ccccccc}
\hline \multirow{2}{*}{ Organisms } & \multicolumn{2}{c}{ Dry season } & \multicolumn{2}{c}{ Wet season } & \multicolumn{2}{c}{ ANOVA } \\
\cline { 2 - 7 } & Min-Max $(\mathrm{Ind} / \mathrm{L})$ & Mean \pm SD & Min-Max(Ind/L) & Mean \pm SD & F Ratio & P \\
\hline Trinema sp. & $150-1,500$ & $707.14 \pm 451.53$ & $150-450$ & $321.43 \pm 124.95$ & $6.035^{*}$ & 0.017 \\
Hesperocorixa obliqua & $300-2,100$ & $1,087.50 \pm 698.55$ & 0 & 0 & $5.839^{*}$ & 0.019 \\
Favella attingata & $150-750$ & $450.00 \pm 244.95$ & 0 & 0 & $4.772^{*}$ & 0.033 \\
Asplanchna herrickii & $600-27,750$ & $7,366.67 \pm 8,293.20$ & $150-14,700$ & $2,034.00 \pm 3,207.36$ & $11.380^{* *}$ & 0.001 \\
A. priodonta & $150-14,250$ & $4,625.00 \pm 3,961.45$ & $150-7,650$ & $1,676.79 \pm 1,796.45$ & $17.287^{* *}$ & 0.000 \\
Brachionusfalcatus & $150-19,500$ & $5,410.71 \pm 5,297.68$ & $150-21,150$ & $2,520.00 \pm 4,618.64$ & $10.247^{* *}$ & 0.002 \\
Trichocercaflagellata & $300-47,400$ & $7,565.63 \pm 12,934.07$ & $150-2,100$ & $785.00 \pm 585.68$ & $10.321^{* *}$ & 0.002 \\
Trichocerca bicristata & $1,800-8,850$ & $4,600.00 \pm 2,326.48$ & $150-750$ & $325.00 \pm 219.37$ & $9.058^{* *}$ & 0.004 \\
Chironomid sp. larva & $150-1,050$ & $570.00 \pm 347.28$ & 0 & 0 & $8.758^{* *}$ & 0.004 \\
\hline *Significant & & & & 0 & &
\end{tabular}

${ }^{* *}$ Highly significant

Table 5. Spatial variation of aquatic microfauna between the three sampling stations

\begin{tabular}{|c|c|c|c|c|c|}
\hline & \multicolumn{5}{|c|}{ Spatial } \\
\hline & \multirow{2}{*}{$\begin{array}{c}\text { Lacustrine } \\
\text { Mean } \pm \text { SD }\end{array}$} & \multirow{2}{*}{$\begin{array}{c}\text { Transition } \\
\text { Mean } \pm \text { SD }\end{array}$} & \multirow{2}{*}{$\begin{array}{c}\text { Riverine } \\
\text { Mean } \pm \text { SD }\end{array}$} & \multicolumn{2}{|c|}{ ANOVA } \\
\hline & & & & F-ratio & $\mathrm{p}$ \\
\hline \multicolumn{6}{|c|}{ Protozoa } \\
\hline Trinemasp. & $495.00 \pm 373.80$ & $350.00 \pm 187.08$ & $1,200.00 \pm 0$ & $4.069^{*}$ & 0.022 \\
\hline \multicolumn{6}{|c|}{ Ciliophora } \\
\hline Favella attingata & $700.00 \pm 308.22$ & $600.00 \pm 150.00$ & 0 & $3.539^{*}$ & 0.035 \\
\hline \multicolumn{6}{|c|}{ Rotifera } \\
\hline Trichocerca flagellata & $5,589.47 \pm 12,330.27$ & $1,488.46 \pm 2,269.88$ & $1,360.71 \pm 1,110.21$ & $6.506^{* *}$ & 0.003 \\
\hline \multicolumn{6}{|c|}{ Arthropoda } \\
\hline Macrocyclops albidus & $150.00 \pm 0$ & 0 & $7,607.14 \pm 8,741.18$ & $3.487^{*}$ & 0.037 \\
\hline
\end{tabular}

Table 6. Diversity indices for zooplankton at various sampling stations

\begin{tabular}{|c|c|c|c|c|c|c|c|c|c|}
\hline \multirow{3}{*}{ Diversity Index } & & \multirow{2}{*}{\multicolumn{2}{|c|}{ Temporal }} & \multicolumn{6}{|c|}{ Spatial } \\
\hline & & & & \multicolumn{2}{|c|}{ Lacustrine } & \multicolumn{2}{|c|}{ Transition } & \multicolumn{2}{|c|}{ Riverine } \\
\hline & & Dry season & Wet season & surface & bottom & surface & bottom & surface & bottom \\
\hline & $\mathbf{N}$ & $1,064,950$ & $1,234,450$ & 303,150 & 222,900 & 666,600 & 59,100 & 608,850 & 264,750 \\
\hline & $S$ & 41 & 51 & 49 & 44 & 57 & 28 & 44 & 41 \\
\hline Richness Index & R1 & 2.88 & 3.56 & 3.80 & 3.49 & 4.18 & 2.46 & 3.23 & 3.20 \\
\hline Simpson's Index & $\lambda$ & 0.12 & 0.05 & 0.15 & 0.08 & 0.05 & 0.09 & 0.13 & 0.08 \\
\hline Hill's 2nd diversity & N2 & 7.99 & 20.19 & 6.87 & 12.92 & 18.27 & 10.80 & 7.72 & 11.97 \\
\hline Shannon's index & $\mathbf{H}^{\prime}$ & 2.58 & 3.24 & 2.52 & 2.93 & 3.22 & 2.69 & 2.69 & 2.81 \\
\hline Hill's 1st diversity & N1 & 13.23 & 25.60 & 12.38 & 18.65 & 25.13 & 14.69 & 14.72 & 16.56 \\
\hline Evenness Index & E4 & 0.60 & 0.79 & 0.55 & 0.69 & 0.73 & 0.73 & 0.52 & 0.72 \\
\hline Evenness Index & E5 & 0.57 & 0.78 & 0.52 & 0.68 & 0.72 & 0.72 & 0.49 & 0.70 \\
\hline
\end{tabular}

is an indication of hyper-eutrophication process. While comparing the seasons, TSI $\mathrm{CR}_{\mathrm{C}}$ value for rainy season was higher than that of the dry season (Table 8). Moreover, the mean TSI $_{\mathrm{CR}}$ value of 58.07 obtained from the ratio of the abundances of Cyclopoida and Calanoida also confirmed the eutrophic status of the reservoir. When comparing the TSI $_{C R}$ values from the Cyclopoida-Calanoida abundance ratio in the different sampling stations, Transition bottom had the highest TSI $_{\mathrm{CR}}$, followed by the Lacustrine surface,

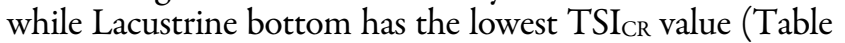
9).

\section{Discussion}

Rotifera species were the most abundant zooplankton recorded within the study, which is in agreement with various studies previously carried out on Opa reservoir (Akinbuwa and Adeniyi, 1991, 1996; Ayodele and Adeniyi, 2006; Akindele and Adeniyi, 2013), as well as data on waterbodies in other parts of Nigeria (Ibrahim, 2009; Arimoro and Oganah, 2010; Okogwu, 2010; Imoobe, 2011 and Ekpo, 2013), as well as other waterbodies in the world (Mageed and Konsowa, 2002; Duggan and Duggan, 2011). However, thirty-one (31) species of Rotifera recorded in the present study connote a reduction in the Rotifer composition of the reservoir as compared to sixty-one (61) species reported by Akinbuwa and Adeniyi in 1991. This is an indication of ecological changes that must have affected the reservoir's zooplankton diversity. Akinbuwa and Adeniyi (1991) also reported that the recorded dominance and abundance of Rotifer species in Opa reservoir, during 
Table 7. Principal component analysis for the zooplankton species based on their abundance

\begin{tabular}{|c|c|c|c|c|c|c|}
\hline & \multicolumn{6}{|c|}{ Components } \\
\hline & 1 & 2 & 3 & 4 & 5 & 6 \\
\hline Eigen value & 6.35 & 4.5 & 4.334 & 3.688 & 2.997 & 2.826 \\
\hline Total \% variance & 10.948 & 7.758 & 7.473 & 6.359 & 5.168 & 4.872 \\
\hline Cumulative variance & 10.948 & 18.706 & 26.179 & 32.537 & 37.705 & 42.577 \\
\hline Asplanchna sp. & $0.929^{* * *}$ & & & & & \\
\hline Asplanchna berrickii & & & $0.539^{* *}$ & $0.560^{* *}$ & & \\
\hline Asplanchna priodonta & & $0.262^{*}$ & $0.293^{*}$ & & & \\
\hline Keratella tropica & & $0.515^{* *}$ & & & $0.316^{*}$ & \\
\hline Keratella lenzi & $0.918^{* * *}$ & & & & & \\
\hline Keratella sp. & & $0.322^{*}$ & & & & \\
\hline Argonotholca foliacea & $0.513^{* *}$ & & $0.299^{*}$ & & & \\
\hline Anuraeopsisfissa & & & & $0.250^{*}$ & & $0.818^{* * *}$ \\
\hline Anuraeopsis sp. & $0.898^{* * *}$ & & & & & \\
\hline Brachionus falcatus & $0.273^{*}$ & & $0.661^{* *}$ & & $0.301^{*}$ & \\
\hline Brachionus angularis & & $0.725^{* * *}$ & & & & \\
\hline Brachionus urceus & & $0.701^{* * *}$ & & & & \\
\hline Platyias quadricornis & & & & & $0.292^{*}$ & \\
\hline Ascomorpha saltans & & $0.424^{*}$ & & & & \\
\hline Ascomorpha ovalis & $0.787^{* * *}$ & & & & & \\
\hline Horaella brehmi & $0.852^{* * *}$ & & & & & \\
\hline Trinema sp. & & $0.663^{* *}$ & & & & \\
\hline Polyarthra remata & & $0.683^{* *}$ & & & & \\
\hline Trichocerca flagellata & & & $0.787^{* * *}$ & $0.374^{*}$ & & \\
\hline Trichocerca cylindrica & $0.922^{* * *}$ & & & & & \\
\hline Mesocyclops sp & & & $0.324^{*}$ & & $0.352^{*}$ & $0.309^{*}$ \\
\hline Horaella brehmi & $0.929^{* * *}$ & & & & & \\
\hline Acanthocyclops vernalis & & & $0.643^{* *}$ & $0.366^{*}$ & & \\
\hline Discorbis sp. & & & & & $0.277^{*}$ & \\
\hline Copepod nauplii & & $0.443^{*}$ & $0.448^{*}$ & & & \\
\hline Cyclops vicinus & & & & & $0.284^{*}$ & \\
\hline Mesocyclops sp. & & $0.261^{*}$ & & & & \\
\hline Thermocyclops inopinus & & & & $0.351^{*}$ & & $0.768^{* * *}$ \\
\hline Acanthocyclops vernalis & & & & & & $0.272^{*}$ \\
\hline Macrocyclops albidus & & & & & & $0.764^{* * *}$ \\
\hline Limnocalanus macrurus & & $0.627^{* *}$ & & & $0.265^{*}$ & \\
\hline Eudiaptomus gracilis & & & & & $0.275^{*}$ & \\
\hline Hesperocorixa obliqua & & & $0.373^{*}$ & & $0.318^{*}$ & $0.344^{*}$ \\
\hline Chironomid larva & & & $0.692^{* *}$ & & & \\
\hline Chaoburus sp. & & & $0.729^{* *}$ & $0.359^{*}$ & & \\
\hline Diaphanosoma brachiurum & & & & $0.289^{*}$ & & \\
\hline Chaoborus sp. & & $0.578^{* *}$ & & $0.277^{*}$ & $0.425^{*}$ & \\
\hline Scapholeberis spinifera & & $0.440^{*}$ & & & $0.415^{*}$ & \\
\hline Moina rostrata & & $0.326^{*}$ & & & & \\
\hline Potamocypris illinoisensis & & & $0.669^{* *}$ & $0.337^{*}$ & & \\
\hline
\end{tabular}

Note: PC loadings $<0.25$ are omitted

${ }^{*}$ Weak loading $(0.25-0.50)$

${ }^{* *}$ Moderate loading $(0.50-0.75)$

${ }^{* * *}$ Strong loading $(>0.75)$ (Yao et al., 2014)

their study, was suggesting that the reservoir is unpolluted. However, results from the current study, especially the trophic status indices, showed the eutrophic feature of the reservoir, hence the reduction in the reservoir's Rotifera species diversity.

The current dominance of Rotifers, as compared to other zooplankton species, could also be attributed to their tolerance to a wide range of impact that makes them adaptable to several environmental conditions such as high organic matter or nutrient loading (Arimoro and Oganah, 2010; Clark et al., 2013; Abioye, 2015). Seasonal and spatial variation in zooplankton abundance was also most 
272

significant for phylum Rotifera, followed by Protozoa and Ciliophora which could be attributed to their ecological segregation related both to feeding behaviour and susceptibility to contaminants (Olaleye and Adedeji, 2005). Moreover, Rotifers had the highest and the lowest abundance in the Transition zone (the deeper part of the reservoir) at both the surface and bottom portion respectively. The higher abundance at the surface level might be suggestive of their feeding habit as most phytoplankton was found closer to the surface (Egborge, 1994; Burger et al., 2002; Moshood, 2002). Akinbuwa (1992) also linked this Rotifer's abundance at the surface water to effect of light on their vertical distribution.

Arthropods, particularly Copepods and Cladocerans were the second most abundant zooplankton recorded in the hereby study, with $33.33 \%$ occurrence from a total of 18 species. This is in contrast with the earlier records on tropical waters, whereas it was reported that Cladocerans are rare, especially the larger zooplankton such as Daphnia sp. (Fernando et al., 1987). This report also contradicts
Tshevelova and Pomazkova's (1995) report of Bosmina sp., as the only Cladoceran representative in Lake Baikal, as well as Coulter's (1991) report of no Cladoceran representative in Lake Tangayika.

Certain Rotifer species characterised with eutrophic communities were recorded. They include Anuraeopsis fissa, Keratella tropica, Filinia sp., Brachionus angularis, $B$. calyciflorus, Trichocerca sp. and Polyarthra sp. Generally, Rotifers, brachiopods and copepods are useful indicators of lake trophic status (Duggan et al., 2001; Offem et al., 2011; Ejsmont-Karabin, 2012) and according to EjsmontKarabin's Trophic State Index (TSI) values obtained based on the occurrence and abundance of these organisms, Opa reservoir could be classified as eutrophic tending towards hyper-eutrophic. This is in contrast to Ogunfowokan et al. (2011) report on the same Opa reservoir, who used Chlorophyll-a to classify the lake as mesotrophic. This change must have stemmed from the consistent inflow of nutrients over these years, which could lead to the aging and deterioration of the lake with time.

Table 8. Estimation of Trophic State Index using Rotifer abundance

\begin{tabular}{|c|c|c|c|c|c|c|c|c|}
\hline & \multicolumn{2}{|c|}{ Temporal } & \multicolumn{6}{|c|}{ Spatial } \\
\hline & & & Lacustrine & & Transition & & Riverine & \\
\hline Organism & Dry season & Wet season & surface & bottom & surface & bottom & surface & bottom \\
\hline Asplanchna sp. 1 & 150 & 0 & 150 & 0 & 0 & 0 & 0 & 0 \\
\hline Asplanchna sp. 2 & 0 & 150 & 0 & 0 & 150 & 0 & 0 & 0 \\
\hline A. berrickii & 132,600 & 50,850 & 53,550 & 29,850 & 24,150 & 6,900 & 48,150 & 20,850 \\
\hline A.priodonta & 83,250 & 46,950 & 19,650 & 29,850 & 19,050 & 5,100 & 23,550 & 33,000 \\
\hline Keratella crassa & 17,400 & 85,500 & 1,650 & 20,550 & 42,450 & 0 & 32,250 & 6,000 \\
\hline Keratella tropica & 2,100 & 91,500 & 4,500 & 600 & 70,650 & 300 & 10,800 & 6,750 \\
\hline Keratella lenzi & 13,500 & 37,950 & 3,000 & 5,550 & 12,900 & 4,800 & 22,350 & 2,850 \\
\hline Argonotholca foliacea & 2,700 & 3,750 & 1,350 & 1,050 & 1,500 & 1,200 & 1,050 & 300 \\
\hline Argonotholca sp. 1 & 150 & 150 & 150 & 0 & 0 & 0 & 0 & 150 \\
\hline Argonotholca sp. 2 & 0 & 150 & 0 & 0 & 0 & 0 & 0 & 150 \\
\hline Anuraeopsis fissa & 0 & 150 & 0 & 0 & 0 & 0 & 150 & 0 \\
\hline Anuraeopsis sp. & 300 & 900 & 300 & 0 & 900 & 0 & 0 & 0 \\
\hline Brachionus falcatus & 75,750 & 63,000 & 13,950 & 6,300 & 54,150 & 11,100 & 25,500 & 27,750 \\
\hline B. angularis & 8,100 & 43,050 & 3,450 & 4,050 & 18,750 & 300 & 20,850 & 3,750 \\
\hline B. calyciflorus & 3,450 & 7,950 & 900 & 1,200 & 7,950 & 0 & 1,350 & 0 \\
\hline B. quadridentatus & 4,050 & 11,550 & 600 & 2,400 & 4,800 & 0 & 5,550 & 2,250 \\
\hline Brachionus urceus & 0 & 150 & 150 & 0 & 0 & 0 & 0 & 0 \\
\hline Platyias quadricornis & 28,650 & 16,950 & 450 & 1,950 & 36,450 & 0 & 6,600 & 150 \\
\hline Ascomorpha saltans & 300 & 150 & 150 & 0 & 150 & 0 & 150 & 0 \\
\hline Ascomorpha sp. & 150 & 0 & 0 & 150 & 0 & 0 & 0 & 0 \\
\hline A. ecaudatus & 150 & 0 & 0 & 0 & 0 & 0 & 0 & 150 \\
\hline A. ecaudis & 0 & 300 & 150 & 0 & 150 & 0 & 0 & 0 \\
\hline A. ovalis & 32,400 & 76,800 & 7,050 & 19,950 & 40,350 & 5,250 & 21,900 & 14,700 \\
\hline Filinia opoliensis & 0 & 11,700 & 6,450 & 2,700 & 2,100 & 0 & 450 & 0 \\
\hline Lecane styrax & 150 & 3,550 & 0 & 0 & 1,050 & 0 & 2,650 & 0 \\
\hline Polyarthra dolichoptera & 0 & 12,600 & 1,200 & 1,200 & 5,850 & 1,200 & 1,950 & 1,200 \\
\hline Polyarthra remata & 0 & 4,500 & 0 & 300 & 3,150 & 0 & 1,050 & 0 \\
\hline Trichocerca flagellata & 121,050 & 23,550 & 85,950 & 20,250 & 18,000 & 1,350 & 10,950 & 8,100 \\
\hline Trichocerca cylindrica & 0 & 7,800 & 450 & 150 & 4,050 & 0 & 2,700 & 450 \\
\hline Trichocerca bicristata & 27,600 & 1,950 & 3,900 & 2,100 & 6,600 & 3,300 & 4,800 & 8,850 \\
\hline Horaella brehmi & 0 & 4,950 & 450 & 0 & 3,600 & 0 & 0 & 900 \\
\hline Mean abundance $(\mathrm{N})$ & $17,869.35$ & $19,629.03$ & $6,759.68$ & $4,843.55$ & $12,222.58$ & $1,316.13$ & $7,895.16$ & $4,461.29$ \\
\hline TSIROT & 71.96 & 72.47 & 66.73 & 64.94 & 69.92 & $\mathbf{5 7 . 9 3}$ & 67.57 & 64.50 \\
\hline
\end{tabular}


Table 9. Estimation of Trophic State Index using Cyclopoda and Calanoida

\begin{tabular}{|c|c|c|c|c|c|c|}
\hline \multirow{2}{*}{ Cyclopoida } & \multicolumn{2}{|c|}{ Lacustrine } & \multicolumn{2}{|c|}{ Transition } & \multicolumn{2}{|c|}{ Riverine } \\
\hline & surface & bottom & surface & bottom & surface & bottom \\
\hline Copepod nauplii & 37,950 & 8,400 & 78,300 & 15,900 & 21,150 & 19,050 \\
\hline Copepod larva & 9,150 & 12,000 & 19,650 & 150 & 60,600 & 14,850 \\
\hline Cyclops vicinus & 7,650 & 1,950 & 39,000 & 1,350 & 14,100 & 43,800 \\
\hline Mesocyclops sp. & 0 & 0 & 19,200 & 0 & 0 & 0 \\
\hline Thermocyclops inopinus & 300 & 0 & 300 & 300 & 1,650 & 0 \\
\hline Acanthocyclops vernalis & 150 & 0 & 0 & 0 & 43,050 & 10,200 \\
\hline Macrocyclops albidus & 12,450 & 7,500 & 19,350 & 0 & 33,900 & 22,800 \\
\hline Total abundance & 67,650 & 29,850 & 175,800 & 17,700 & 174,450 & 110,700 \\
\hline \multicolumn{7}{|l|}{ Calanoida } \\
\hline Limnocalanus macrurus & 150 & 2,700 & 600 & 0 & 7,650 & 4,950 \\
\hline Senecella calanoides & 1,800 & 600 & 28,800 & 300 & 2,850 & 15,600 \\
\hline Diaptomussp & 600 & 2,250 & 2,400 & 0 & 300 & 0 \\
\hline Eudiaptomus gracilis & 300 & 1,950 & 750 & 450 & 0 & 150 \\
\hline Calanussp & 300 & 0 & 2,100 & 0 & 1,350 & 600 \\
\hline Total abundance $(\mathbf{N})$ & 3,150 & 7,500 & 34,650 & 750 & 12,150 & 21,300 \\
\hline TSI $_{\mathrm{CR}}$ & 62.18 & 53.62 & 54.85 & 62.66 & 60.13 & 54.97 \\
\hline
\end{tabular}

\section{Acknowledgements}

The authors will like to recognise the efforts of the following people and bodies for their immense contribution to the success of this research work: Dr. A.I. Aduwo, Mr. Adesakin Taiwo, Mrs. Helen Abioye, Mrs. Kemi Odeyemi and the entire team in Hydrobiology Laboratory, Obafemi Awolowo University, Ile-Ife, Nigeria.

\section{References}

Abioye HY (2015). Planktonic community and primary productivity of Owalla Reservoir, Osun state, Nigeria. M.Sc. Thesis. Department of Zoology, Obafemi Awolowo University, Ile-Ife, Osun state, Nigeria.

Adedeji AA, Aduwo AI, Aluko OA, Awotokun F (2011). Effect of chicken droppings as organic fertilizer on water quality and planktonic production in an artificial culture media. Ife Journal of Science 13(2):239-249.

Adesakin, TA, Adedeji AA, Aduwo AI, Taiwo YF (2017). Effect of discharges from re-channeled rivers and municipal runoff on water quality of Opa reservoir, Ile-Ife, Southwest Nigeria. African Journal of Environmental Science and Technology 11(1):56-70.

Akinbuwa $\mathrm{O}$ (1992). A preliminary study of diurnal vertical distribution of Rotifers in Opa Reservoir, Nigeria. Journal of Aquatic Science 7:19-28.

Akinbuwa O, Adeniyi IF (1991). The Rotifera fauna ofOpa reservoir,Ile-Ife, Nigeria. Journal of African Zoology 105(5):383-391.

Akinbuwa O and Adeniyi IF (1996). Seasonal variation, distribution and interrelationships of Rotifers in Opa Reservoir, Nigeria. African Journal ofEcology 34:351-363.

Akindele EO, Adeniyi IF (2013). A study of the physicochemical water quality, hydrology and zooplankton fauna of Opa Reservoir. African Journal of Environmental Science and Technology 7(5):192-203.

Arimoro FO, Oganah AO (2010).Zooplankton community responses in a perturbed tropical stream in the Niger Delta, Nigeria. The Open Environmental and Biological Monitoring Journal 3(1):1-11.
Ayodele HA, Adeniyi IF (2006). The zooplankton fauna of six impoundments on the river Osun, Southern Nigeria. The Zoologist $1(4): 49-67$.

Burger DF, Hogg ID, Green JD (2002). Distribution and abundance of zooplankton in the Waikato River, New Zealand. Hydrobiologia 479(1):31-38.

Burns NM, Rutherford JC (1998). Results of monitoring New Zealand lakes, 1992-1996. NIWA Hamilton Client Report MFE80216, Hamilton, New Zealand. In: https: //doi.org /10.1080 /07438149909354122.

Carpenter SR, Kitchell JF (1993). The trophic cascade in lakes. Cambridge University Press, Cambridge pp 301-335.

Casanova SMC, Henry R (2004). Longitudinal distribution of Copepoda populations in the transition zone of Paranapanema river and Jurumirin reservoir (Sao Paulo, Brazil) and interchange with two lateral lakes. Brazilian Journal of Biology 64(1):11-26.

Clark EO, Aderinola OJ and Adeboyejo OA (2013). Dynamics of Rotifer Populations in a Lagoon Bordered by Heavy Industry in Lagos, Nigeria. American Journal of Research Communication 1(4):172-192.

Coulter GW (1991). Pelagic fish. In: Coulter GW (Ed). Lake Tangayika and itslife. Oxford University Press, London pp 111-138.

Duggan IC, Duggan KS (2011). Are botanical gardens a risk for zooplankton invasions? Biological Invasions 13:2997-3003.

Duggan IC, Green JD, Shiel RJ (2001). Distribution of Rotifers in North Island, New Zealand, and their potential use as bioindicators of Lake Trophic State. Hydrobiologia 446-447:155-157.

Egborge ABM (1994). Water pollution in Nigeria: Biodiversity and chemistry of Warri River, Nigeria. Ben Miller Publisher, Warri, Nigeria pp 254 .

Ejsmont-Karabin J (2012). The usefulness of zooplankton as lake ecosystem indicators: Rotifer trophic index. Polish Journal of Ecology 60:339-350.

Ejsmont-Karabin J, Karabin A (2013). The suitability of zooplankton as lake ecosystem indicator; Crustacean trophic state index. Polish Journal of Ecology61(3):561-573. 
274

Ekpo I (2013). Effect of physico-chemical parameters on zooplankton species and density of a tropical rainforest river in Niger Delta, Nigeria using canonical cluster analysis. The International Journal of Engineering and Science 2(4):13-21.

Fawole OO, Arawomo GAO (2000). Fecundity of Sarotherodon galilaeus (Pisces: Cichlidae) in the Opa reservoir, Ile-ffe, Nigeria. Revista de Biología Tropical 48(1):201-204.

Fernando CH (2002). A guide to tropical freshwater zooplankton: identification, ecology and impact on fisheries. Backhuys publishers, Leiden, The Netherlands pp 291.

Fernando CH, PagijJC, Rajapaksa R (1987). Daphnia in tropical lowlands. Member of Institute of Hydrobiology 45:107-141.

Goswami SC (2004). Zooplankton methodology, collection and identification - a Field Manual. National Institute of Oceanography. Dhargalkar, V.K. Verlecar,X.N.(Eds). Dona Paula, Goa pp 205-300.

Haberman J, Haldna M (2014). Indices of zooplankton community as valuable tools in assessing the trophic state and water quality of eutrophic lakes: long term study of Lake Vortsjarv. Journal of Limnology 73(2):263-273.

Ibrahim S (2009). A survey of zooplankton diversity of Challawa River, Kano and evaluation of some of its physicochemical conditions. Bayero Journal of Applied Sciences 2(1):19-26.

Imoobe TOT (2011). Diversity and seasonal variation of zooplankton in Okhuo River, a tropical forest river in Edo State, Nigeria. Centrepoint Journal 17(1):37-51.

Jeje CY, Fernando CH (1986). A practical guide to the identification of Nigerian zooplankton (Cladocera, Copepoda and Rotifera). Kanji Lake Research Institute, New Bussa, Nigeria, Publication pp 142.

Mageed AA, Konsowa AH (2002). Relationship between phytoplankton, zooplankton and fish culture in a freshwater fish farm. Egyptian Journal of Aquatic Biology and Fisheries 16(2):183-206.

Mitsch WJ, Gosselink RL (2000). Wetlands. $3^{\text {rd }}$ Ed, John Wiley, New York, USApp 920.
Moshood KM (2002). A pre-impoundment survey of the flora and fauna communities of Oyun Lake in Ilorin, Kwara state, Nigeria. Nigerian Journal of Pure and Applied Sciences 17:1200-1209.

Offem BO, Ayotunde EO, Ikpi GU, Ada FB, Ochang SN (2011). Plankton-based assessment of the trophic state of three tropical lakes. Journal of Environmental Protection 2:304315.

Ogunfowokan AO, Akanni MS, Ajibola RO, Ayinde FO (2011). Trophic status and physicochemical parameters of three reservoirs in Osun State, Nigeria. Ife Journal of Science 13(1):27-44.

Okogwu OI (2010). Seasonal variations of species composition and abundance of zooplankton in Ehoma Lake, a floodplain lake in Nigeria. Revista De Biología Tropical 58(1):171-182.

Olaleye VF, Adedeji, AA (2005). Water and planktonic quality of a palm oil effluent impacted river in Ondo state, Nigeria. International Journal of Zoological Research 1(1):15-20.

Paterson M (2001). Protocols for measuring biodiversity; zooplankton in freshwaters. www. eman-resecaleman /ecotools/ protocols /freshwater /zooplankton.

Sarkar SK, Chaudhary B (1999). Role of some environmental factors on the fluctuations of plankton in a lentic pond at Calcutta, Limnological Research in India, Daya Publishing House pp 108-130.

SPSS (Statistical Package for Social Sciences) (2012). Statistical Package for the Social Sciences Base 21 for Windows. Chicago, IL: SPSS

Tshevelova NG, Pomazkova I (1995). The Order Cladocera. In: O. Timoshkin (ed.). Guide and Key to Pelagic Animals of Baikal. Nauka, Novosibirisk pp 431-474.

Yao H, Qian X, Gao H, Wang Y, Xia B (2014). Seasonal and Spatial variations in Heavy Metals in Two typical Chinese Rivers: Concentrations, Environmental Risks and Possible sources. International Journal on Environmental Resource and Public Health 11:11860-11878. 